\title{
Strategies for Promoting Entrepreneurial Skills in Science Education Students for Poverty Eradication
}

\author{
Agommuoh, P. C. (Ph.D) ${ }^{1}$, Ndirika, M. C. (Ph.D $)^{2}$ \\ ${ }^{1,2}$ Department of Science Education, Michael Okpara University of Agriculture, Umudike.
}

\begin{abstract}
The rate of unemployment in Nigeria is alarming. There is need for science students to develop entrepreneurial skills which is a way of reducing unemployment and becoming self-reliant thereby eradicating poverty. These skills can only be developed through efficient and effective knowledge of science education. This study therefore employed a descriptive survey design to investigate strategies in promoting entrepreneurial skills for science education students for poverty eradication. Forty-one science education students from Michael Okpara University of Agriculture Umudike Umuahia in Abia State were randomly sampled and used for the study. Two research questions and one hypothesis tested at 0.05 level of significance guided the study. The instrument for data collection was the researcher's self developed modified four point Likert Scale type questionnaire on strategies in promoting entrepreneurial skills for science education students for poverty eradication whose reliability coefficient was obtained as 0.81 . Data collected were analyzed using mean for the research questions and t-test for the hypothesis. The result obtained indicated that classroom assessment technique, case study/discussion method, cooperative learning strategies, using questions, conference style learning, use of writing assignments, dialogues and ambiguity are some of the methods/strategies the science teacher can use while teaching science education students in order to promote entrepreneurial skills in their students for poverty eradication. Recommendations were made to include science teachers teaching science education students science in such a way that the students will be able to imbibe scientific knowledge.
\end{abstract}

Keywords: Science Education, Poverty, Poverty Eradication and Entrepreneurial skills.

\section{Introduction}

Unemployment is one of the most critical problems facing Nigeria today. According to World Bank statistics, in Bakere (2013), unemployment rate among the youth is over 38 percent with secondary school graduates mostly found among unemployed rural population, accounting for about half of the population of over 150 million people, while university and polytechnic graduates make up the rest. The implication is that if the rate of unemployment is not checked, it will lead to more graduates being recruited into the rank of oil theft syndicates, armed robbers, kidnappers, militants and insurgents (Uka, 2015). The government had made some efforts to check this trend and create jobs but the truth is that Nigerian youths have to be self - reliant to be employed since no government can effectively and gainfully employ all its citizens.

One of the consequences of unemployment is poverty. Poverty is general scarcity or the state of one who lacks a certain amount of material possessions or money. It is a multifaceted concept, which includes social, economic, and political elements. Eradicating poverty in all its forms and dimensions, including extreme poverty, is the greatest global challenge and an indispensable requirement for national and sustainable development. The first Sustainable Development Goal aims to "End poverty in all its forms everywhere". Its seven associated targets aims, among others, to eradicate extreme poverty for all people everywhere, reduce at least by half the proportion of men, women and children of all ages living in poverty.

To totally address the issue of unemployment and eradicate poverty in Nigeria, there is a great need for the acquisition of entrepreneurial skills for employable individuals. These entrepreneurial skills may not be efficiently and effectively acquired without the knowledge of science education. There is therefore a need to investigate the strategies in promoting entrepreneurial skills in science education students for eradicating poverty. Hence this study.

The knowledge of science education prepares students to be actively engaged and responsible citizens, creative and innovative, able to work collaboratively and fully aware of and conversant with the complex challenges facing society (European Commission, 2015). The knowledge of science helps in explaining and understanding the world around us. Science education is very important in promoting a culture of scientific thinking and inspiring citizens to use evidence-based reasoning for decision making; ensuring citizens have the confidence, knowledge and skills to participate actively in an increasingly complex scientific and technological world; developing the competencies for problem- solving and innovation, as well as analytical and critical thinking that are necessary to empower citizens to lead personally fulfilling, socially responsible and professionally-engaged lives and inspiring children and students of all ages and talents to aspire to careers in science and other occupations and professions that underpin our knowledge and innovation-intensive societies 
and economies, in which they can be creative and accomplished. The goals underlying science curriculum and instruction are

$>$ Science education should develop fundamental understandings of natural systems (Scientific Knowledge)

$>$ Science education should develop a fundamental understanding of, and ability to use, the methods of scientific inquiry (Scientific Method).

$>$ Science education should prepare citizens to make responsible decisions concerning science-related social issues (Social Issues).

$>$ Science education should contribute to an understanding and fulfillment of personal needs, thus contributing to personal development (Personal Needs).

$>$ Science education should inform students about careers in the sciences (Career Awareness).

$>$ Science education should excite and enthuse children with a sense of awe and wonder at the natural world.

$>$ Science students develop an appreciation of how science has contributed to the historical and cultural development of our society.

$>$ Science education should give students practical experience of how scientists make observations of the natural world, come up with hypotheses and do experiments to obtain evidence to support or disprove these hypotheses.

$>$ Science education should cause children to understand the importance of evidence when making decisions and to be able to judge whether the claims of the media, advertisers, politicians, journalists, etc, are evidence-based and reliable.

$>$ Science education should give pupils enough evidence-based knowledge to be able to make informed personal judgments in order to lead healthy, safe, comfortable and environmentally sustainable lives.

$>$ Science education should develop awareness of the conclusions of important scientific theories in a concrete and accessible way.

$>$ Science education should develop pupils' understanding and experience of the scientific method, to understand its value and limits, and to enable them to apply the method.

$>$ Science students should be proficient at practical work, use of scientific equipment efficiently to know, understand at an abstract level, and be able to apply important scientific theories.

The implication is that a scientists must be persistent, self-confident and patient, inquisitive, thorough, competent, risk-taker, resourceful, rationalization of every act, optimistic, realistic, systematic, determined, very hardworking, resilience (Enukoha, 2002 and Uka, 2006). The modern world science teachers need to understand and appreciate the dependence of a modern society in science and the changes we now have in the society due to the advent of science and technology. Science teachers should also understand the social use of entrepreneurial skills in their day to day science affairs in the classroom, outside the classroom and in the society at large (Adeyemo, 2009). According to Das (2006), science teachers need to understand and acquire the basic entrepreneurial skills that will make them function effectively in the school setting. Based on this, science teachers need some essential entrepreneurial skills that will increase their efficiency and effectiveness in knowledge delivery and management of resources in the school environment. These according to Adeyemo (2009) include: instructional leadership skills, management skills, communication skill, collaboration skill, vision development skills, change management skills, analysis skills, process skills, evaluation skills and parsimony/economy skills. There is therefore the need to identify strategies that the science education teachers can use to promote entrepreneurial skills in their students in order to eradicate poverty. Various strategies have been identified to help in promoting entrepreneurial skills in science education students for eradication of poverty. Odubunmi (1983) identified classroom assessment technique as one of such strategies. Screen (1976), Odubunmi (1983), Okebukola (1984) and Scott (1998) opined that case study/discussion method, cooperative learning strategies, using questions, conference style learning, use of writing assignments, dialogues and ambiguity as methods/strategies the science teacher can use while teaching students in order to promote entrepreneurial skills in their students for poverty eradication. There is therefore the need to find out from science education students, strategies that can be used in the teaching of science to promote entrepreneurial skills for poverty eradication. Entrepreneurial skill can be defined as the ability to create something new with value by devoting the necessary time and effort, assuming the accompanying financial, psychic and social risks, and receiving the resulting rewards of monetary and personal satisfaction and independence (Hisrich \& Peters, 2002). According to Salgado-banda, (2005), entrepreneurial skills is the ability to have self-belief, boldness, tenacity, passionate, empathy, readiness to take expert advice, desire for immediate result, visionary and ability to recognize opportunity. For an entrepreneur to be successful, there are some skills or traits he has to acquire. These skills or traits include willingness to take risks, perseverance, ability to work under pressure, ability to initiate, take responsibility and make decisions, an innovative and creative thinker, self-motivated and disciplined able to research effectively, financial literacy, that is financial skills such as book-keeping and calculating tax, able to plan, coordinate and organize effectively, management skills (ability to manage time and 
people successfully), communication skills (e.g ability to sell ideas and persuade others), optimism, resilience, courage, determination. A critical look at the goals of science education shows that the entrepreneurial skills listed above are embedded in them. To totally address the issue of unemployment in Nigeria, there is a great need for the acquisition of entrepreneurial skills for employable individuals. These entrepreneurial skills may not be efficiently acquired without effective knowledge of science education. Science education is needed in all facets of life. There is therefore a need to investigate the strategies involved in promoting entrepreneurial skills in science education students in order to eradicate poverty. Hence the study. The purpose of this study therefore is to investigate science education students' assessment of strategies that can be used in the teaching of science education students to promote entrepreneurial skills in them for poverty eradication.

\section{Research Questions}

The following research questions guided the study.

1. What are the scores of science students on the assessment of strategies for promoting entrepreneurial skills in science education students for poverty eradication?

2. What are the scores of male and female science students on the assessment of strategies for promoting entrepreneurial skills in science education students for poverty eradication?

The hypothesis below guided the study.

\section{Hypothesis}

Ho: There is no significant difference in the scores of male and female science students' assessment of strategies for promoting entrepreneurial skills in science education students for poverty eradication.

\section{Method}

The study adopted the descriptive survey design. Random sampling technique was used to sample 41 (17males and 24 females) science education students from Michael Okpara University of Agriculture Umudike Umuahia of Abia State. Two research questions and one null hypothesis guided the study. The instrument for data collection was the researcher's developed questionnaire on the strategies for promoting entrepreneurial skills in science education students for poverty eradication of the four point Likert scale type of strongly Agree (SA), Agree (A), Disagree (D) and Strongly Disagree (SD) which are rated 4, 3, 2 and I respectively. The instrument was validated and its coefficient of reliability obtained as 0.81 . Data collected was analyzed using mean to answer the research questions and t-test statistics to test the hypothesis.

\section{Results}

Table 1: Mean scores of senior secondary school students' assessment of Strategies for Promoting Entrepreneurial Skills in Science Education Students for Poverty Eradication.

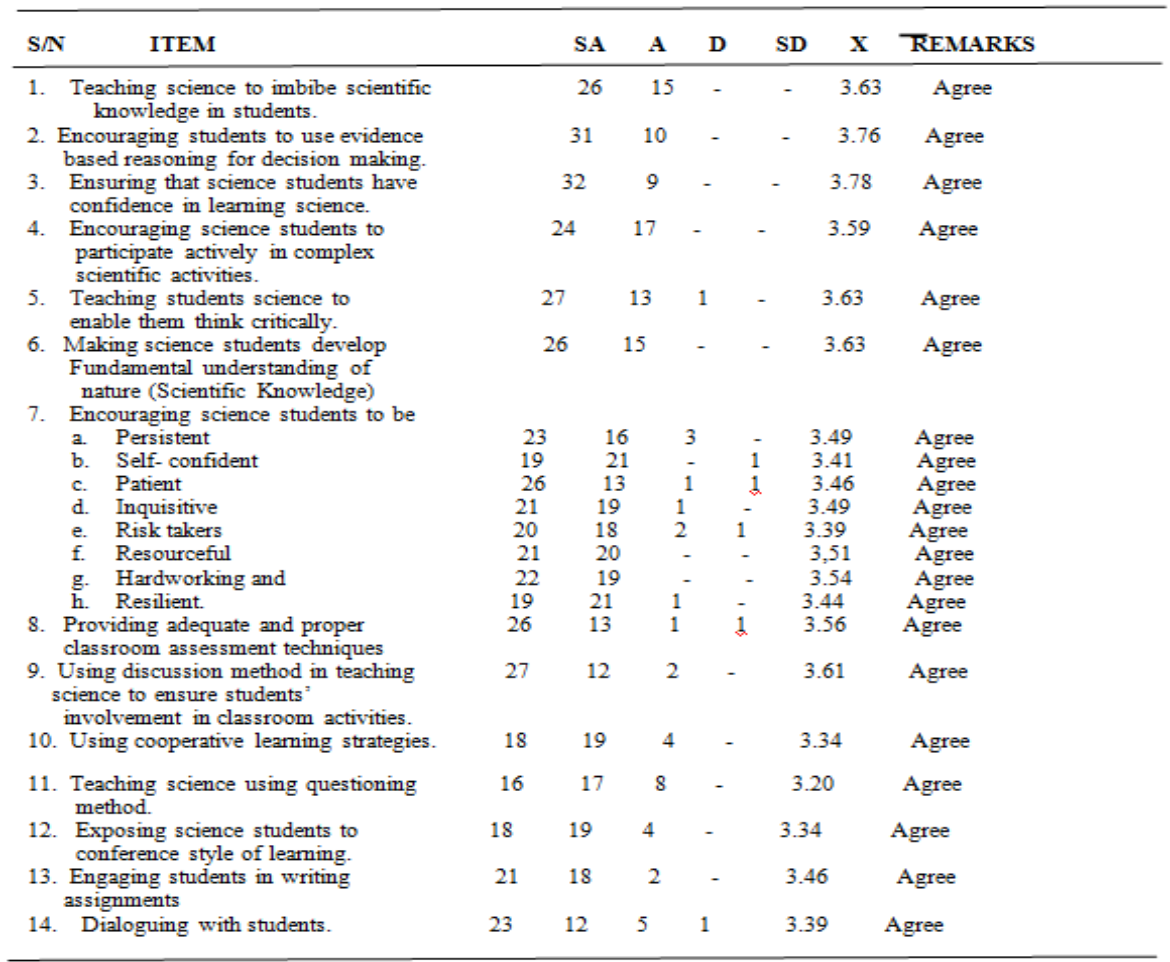


Table 1 above clearly showed that all the items have mean values greater than 2.5 which is the mean value of the four point scale used in the study. This means that all the science education students agreed that these items are all strategies in promoting entrepreneurial skills in science education students for poverty eradication.

Table 2: Mean scores of male and female science students assessment of entrepreneurial skills in science education for poverty eradication

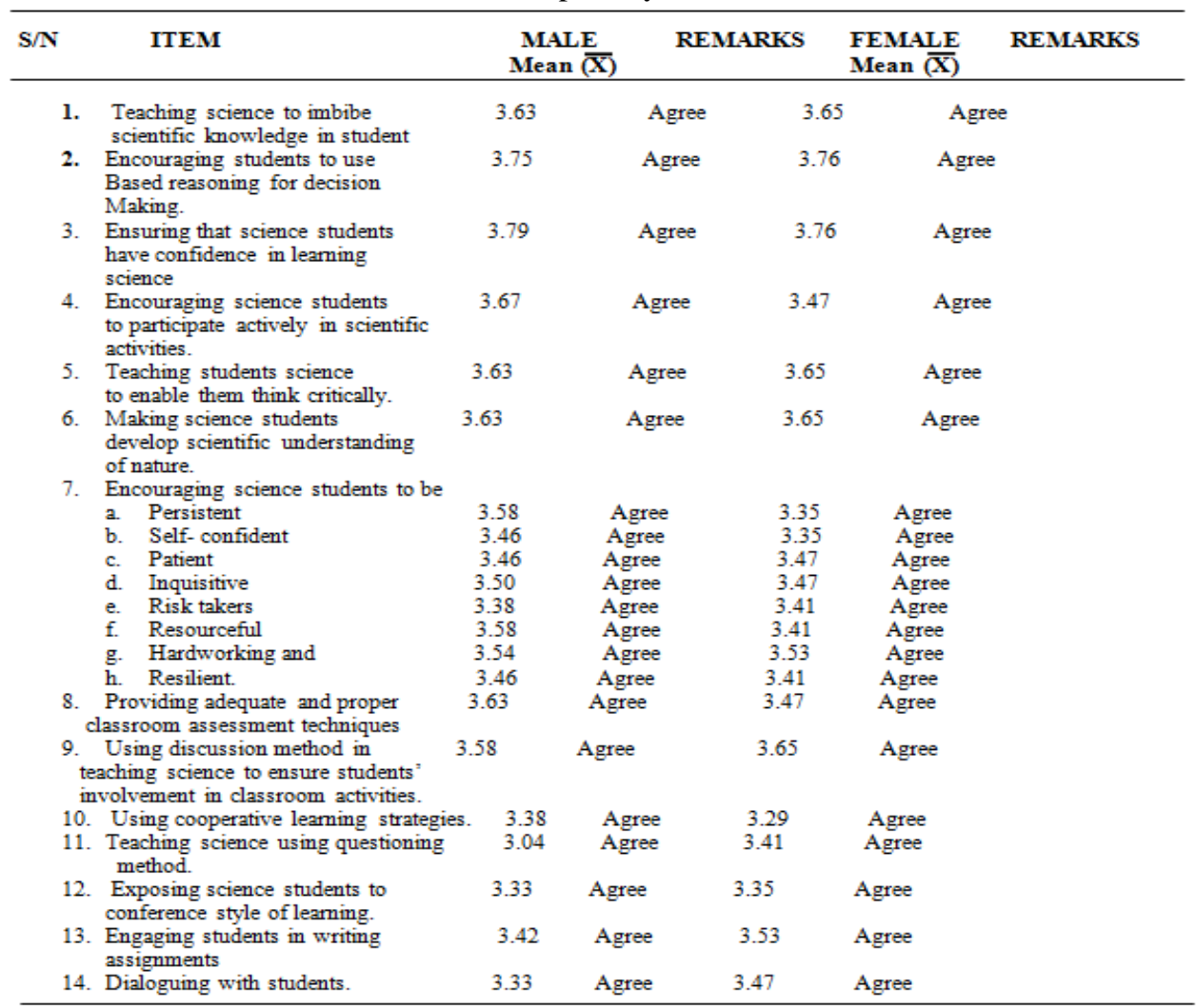

Result in table 2 shows that all the items have mean values greater than 2.5 meaning that all the science education students, both males and females agreed that the fourteen items listed above are strategies in promoting entrepreneurial skills in science education students for poverty eradication.

Table 3: t-test difference between the mean scores of male and female science students response on strategies for promoting entrepreneurial skills in science education students for poverty eradication.

\begin{tabular}{|l|l|l|l|l|l|l|l|}
\hline Gender & $\mathbf{N}$ & Mean & SD & df & t-cal & t-tab & P =0.05 \\
\cline { 1 - 6 } Male & 24 & 3.50 & .654 & 39 & -.163 & 1.98 & Not Sig \\
\hline Female & 17 & 3.51 & .588 & & & & \\
\hline
\end{tabular}

Result in table 3 shows that the calculated t-value of -.163 is less than the critical t-value of 1.98. That is $\mathrm{t}$-calculated $<\mathrm{t}$-critical at $\mathrm{p}<.05$ is not significant. This means that there is no gender difference in the responses of science education students on the strategies in promoting entrepreneurial skills in science education for poverty eradication. The null hypothesis of no significant difference in the mean scores of male and female science students' response on strategies for promoting entrepreneurial skills in science education students for poverty eradication is accepted.

\section{Discussion}

Results in tables 1 and 2 clearly showed that all the items have mean values greater than 2.5 meaning that all the science education students, both males and females agreed that the fourteen items listed above strategies in promoting entrepreneurial skills in science education students for poverty eradication. This result is in agreement with Enukoha, (2002) and Uka, (2006) who opined that a scientists must be persistence, selfconfident and patient, inquisitive, thorough, competent, risk-taker, resourceful, rationalization of every act, optimistic, realistic, systematic process, determined, very hardworking, resilience. The result also agrees with 
Odubunmi (1983), Screen (1976), Okebukola (1984) and Scott (1998) who identified classroom assessment technique, case study/discussion method, cooperative learning strategies, using questions, conference style learning, use of writing assignments, dialogues and ambiguity as methods/strategies the science teacher can use while teaching science education students in order to promote entrepreneurial skills in their students for poverty eradication. Items 1-6 in both tables 1 and 2 show that the knowledge of science will enhance entrepreneurial skills development in science education students. This also agrees with the goals of the science curriculum which includes students developing fundamental understandings of natural systems (Scientific Knowledge), having the ability to use scientific method of inquiry, making responsible decisions, being proficient at practical work and to use of scientific equipment efficiently. The implication is that for entrepreneurial skills to be promoted in science education students, such students must be taught science properly.

\section{Conclusion}

For a country like Nigeria with a high percentage of unemployed youths, there is need for such youths to have entrepreneurial skills to be self employed in other to eradicate poverty. Science education is indispensable to economic development and poverty eradication and should therefore be effectively taught to students since a balanced science education system promotes not only economic development but also productivity. Science teachers will go a long way to help science education students to generate individual income per capita if the above listed strategies are applied and used in promoting entrepreneurial skills in their science education students in other to eradicating poverty.

\section{Recommendation}

Based on the findings the following recommendations are made

1. Science education teachers should teach science to imbibe scientific knowledge in their students.

2. Science teachers should ensure that science students have confidence in learning science and also participate actively in scientific activities.

3. Science students should be encouraged to be persistent, self- confident, patient, inquisitive, take risks, resourceful, hardworking and resilient.

4. University managements must make sure that qualified science education teachers are employed to teach the science education students in their various universities.

\section{References}

[1]. B. Bakere, Addressing Youth Unemployment in Nigeria.2013, http://businessdayonline.com/2013/11 /addressing- Retrieved 29th June, 2014.

[2]. N. K. Uka, Developing Entrepreneurial Skills in Secondary School Students through Effective Mathematics Education in Aba Nigeria. International Journal of Education Learning and Developing. 3 (7) 2015, 1-11.

[3]. European Commission, Commission Staff Working Document. Turkey 2015 Report.

[4]. O. I. Enukoha, Security as vocation. Scientific method and the development of security consciousness in the Nigerian Hotel Industry. Calabar; African Journal of Vocational Education 2(1, 2002).

[5]. N. K.Uka, Teachers' Mathematical Attitude Ethno mathematical Knowledge and Primary School Pupils Academic Achievement in Mathematics in Abia State, Nigeria.. 2006. Unpublished Ph.D Thesis, University of Calabar, Calabar.

[6]. S. A. Adeyemo, Understanding and Acquisition of Entrepreneurial Skills: A Pedagogical Re-orientation for Classroom Teacher in Science Education. Journal of Turkish Science Education. 6 (3), 2009, 57-65.

[7]. R. C. Das, Science Teaching in Schools, Sterling publishers private limited, 2006. New Delhi- 110020.

[8]. E. O. Odubunmi, The Effect of Socio Economic Background and Teaching Strategies on learning outcomes in Integrated Science. 1983. Unpublished Ph.D. Thesis, University of Ibadan.

[9]. C. C. Screen, Skills performance and Memory. In Welford A.T. (Ed) Skilled Performance: Perceptual and Motor Skills. Scott, 1976, Foresman and Company, U.S.A.

[10]. P. A. O. Okebukola, . Effects of cooperative, competitive and individualistic laboratory Interaction patterns on student's performance in Biology. 1984. Unpublished Ph.D thesis, University of Ibadan, Nigeria.

[11]. P. Scott, Teacher talk and meaning making in science classrooms: a Vygotskian Analysis and review. Studies in Science Education. 32, 1998, 45-50.

[12]. D. Hisrich, Richard and P. Peters, Michael . Entrepreneurship. Boston: McGraw- Hill/Irwin.2002.

[13]. H. Salgado-Banda, Entrepreneurship and Economic Growth; An Empirical Analysis.2005. 